\title{
Optimization Of Microbial Consortium (AB-101) Performance In Palm Oil Mill Effluent (POME) Treatment Via Response Surface Methodology (RSM)
}

\author{
Muhammad Adib Abidi ${ }^{1}$, Nur Hanis Hayati Hairom ${ }^{*}$ (D), Rais Hanizam Madon ${ }^{1}$, Angzzas Sari Mohd \\ Kassim ${ }^{1}$, Dilaeleyana Abu Bakar Sidik ${ }^{2}$, Adel Ali Saeed Al-Gheethi ${ }^{3}$ \\ 1 Faculty of Engineering Technology, Universiti Tun Hussein Onn Malaysia, Hab Pendidikan Tinggi Pagoh, KM 1, Jalan \\ Panchor, 84600, Muar, Johor, Malaysia \\ 2 Center of Diploma Studies, Universiti Tun Hussein Onn Malaysia, Hab Pendidikan Tinggi Pagoh, KM 1, Jalan Panchor, \\ 84600, Muar, Johor, Malaysia \\ 3 Faculty of Civil Engineering and Built, Jalan FKAAB Universiti Tun Hussein Onn Malaysia, 86400 Parit Raja, Johor, \\ Malaysia \\ * Correspondence: nhanis@uthm.edu.my;
}

Scopus Author ID 35271243100

Received: 6.08.2020; Revised: 2.09.2020; Accepted: 5.09.2020; Published: 10.09.2020

\begin{abstract}
Biological treatment of POME has been well known for its efficiency to degrade the organic pollutants prior to discharge into the water stream. Yet, biological treatment on its own was allegedly inadequate to comply with the standard imposed by the Department of Environment (DOE) Malaysia for the final discharge of POME. In this study, a bio activator consists of microbial consortium AB101 is analyzed towards its effectiveness in enhancing or boosting the biological treatment of raw POME. The optimum volume ratio of microbial consortium AB101 and nutrition (molasses) in the bio-activator prepared as well as dosing of the bio-activator into the POME were determined by using Response Surface Methodology (RSM) via Design-Expert software (version 7.1.5). The study has been carried out to determine the optimum value of those three independent variables; i) volume percentage of AB101; ii) volume percentage of molasses; and iii) dosage of bio-activator. The optimum value of each factor is corresponding to the value of response; the Chemical Oxygen Demand (COD) reduction percentage of treated POME. The highest COD reduction recorded $(91.25 \%)$ was recorded at the values of factors as follows; volume percentage of AB101 (0.1\%), the volume percentage of molasses $(9.96 \%)$, and dosage of bio-activator (33.6 ppm).
\end{abstract}

Keywords: bio-activator; microbial consortium; molasses; POME.

(C) 2020 by the authors. This article is an open-access article distributed under the terms and conditions of the Creative Commons Attribution (CC BY) license (https://creativecommons.org/licenses/by/4.0/).

\section{Introduction}

United States Department of Agricultural (USDA), an economic research service, has reported that palm oil production in Malaysia has been growing drastically since as early as from 1965, from 151,000 ton/year [1], keep escalating to 19,516,141 ton/year and 19,858,367 ton/year respectively in 2018 and 2019 as reported by Malaysian Palm Oil Berhad (MPOB) in the annual report on the official website [2,3]. In 1990, there were 261 palm oil mills operating, resulting in a total of 42,874,000 fresh fruit bunch per year (ffb/year) of capacity [4]. Meanwhile, recently in 2018, the number of mills has increased to 451 mills with an almost tripled total capacity of $112,442,000 \mathrm{ffb} /$ year [5]. According to [6], the main feed or raw materials of the palm oil milling process is free fruit bunch (FFB), and palm oil mills are 
responsible for generating crude palm oil (CPO) and kernel as main products from FFB. Along the process, byproducts are produced from different points of the palm oil process, including empty fruit bunch (EFB), mesocarp fiber (MF), kernel shell (KS) and palm oil mill effluent (POME) [7].

Amongst all byproducts, POME is the most concerning due to its abundancy in its capacity with respect to CPO produced. For every 100 tonnes of FFB to be processed, 67 tonnes of POME will be produced. Meanwhile, the main product (CPO) is only 22 tonnes [8]. Physically, POME is a thick, dark brownish and non-toxic liquid waste with remarkable stench [9]. What is worse, POME has a controversial quality or water parameters, especially in organic load contents indicated by high chemical oxygen demand (COD) and biological oxygen demand (BOD) of $\sim 51,000 \mathrm{mg} / \mathrm{L}$ and $\sim 25,000 \mathrm{mg} / \mathrm{L}$, respectively [10]. Therefore without proper treatment of POME, it potentially would diminish the dissolved oxygen amount for aquatic lives once it is discharged to the river since the oxygen depletion of raw POME is 100 times more severe than raw sewage [11]. In the long term run, it potentially causes water pollution, food source depletion, and extinction of water resources [12]. Therefore, it is no longer an option; it is obligatory to treat POME prior to its discharge into the river.

The most common primary treatment of POME is conventional biological treatment via anaerobic degradation, owing to the relatively lower capital and operational cost due to its simple design and minimal energy consumption. The open ponding systems are commonly used in biological treatment then replaced by high rate digester to save space and improve efficiency [13]. Although the anaerobic treatment system is by far the best approach to primarily treat POME, the main drawbacks of the process are; it possesses low treatment efficiency, requires large areas, and requires high hydraulic retention time (HRT) ranging between 30 and 90 days [14]. Nevertheless, it is also only able to reduce BOD and COD down to an average of only $200 \mathrm{mg} / \mathrm{L}$ and $800 \mathrm{mg} / \mathrm{L}$, respectively [15]. These drawbacks are mainly due to that the microbial community in the POME itself that is responsible for the degradation of the organic pollutants require a certain amount of time to adapt, mature in the environment before they start degrading the organic matters [16].

Therefore, in the last decade, palm oil mills have been seen to make a major shift into tertiary treatments using various technologies such as membrane filtration [17], coagulationflocculation [18,19], photocatalytic [20,21], and adsorption [22,23]. All of these tertiary treatment technologies are very promising in a further treat and improve POME characteristics, consequently complying $20 \mathrm{mg} / \mathrm{L}$ of BOD with ease. However, the performance of the wastewater treatment process has a great relationship with the economic cost [24]. For example, membrane technology was evaluated as the best tertiary treatment on the environmental impact among several technologies from the tertiary treatment of POME. However, despite the effluent of the membrane system possesses the best quality, the costs of electricity, capital installation, inventory, and chemical consumption were quite high [24]. Despite its high efficacy, the membrane is also well known for its short lifetime and has consequences; it directly increases operational cost due to a higher frequency of maintenance $[8,25]$.

Therefore, the purpose of the project is solely to improve the quality of POME by polishing up and enhancing the anaerobic degradation of POME by using fruits-based microbial consortium (AB-101), via just using a biological treatment, without tertiary treatment. According to a study done by Birintha Ganapathy and her colleagues, bacteria, molds, yeasts, and fungus are the microorganisms that can perform complete degradation of 
oil-based wastewater such as POME [26]. Mixed cocultures of microorganisms in AB-101 are used mainly when complex material in POME, acts as a substrate to produce less hazardous end product [27]. These microbial groups have two characteristics: communication between members of the consortia for the exchange of metabolites and promotion of the division of labor and degradation of complex substrates [28,29]. Therefore, the objectives of this project are to analyze the very basic variables that can be optimized in order to get the best results out of using AB101 to treat POME. The overall objective of this study is to provide a preliminary understanding of the influence of AB-101 during POME treatment. AB101 possesses a very high potential as the solution for ineffective conventional biological treatment, as well as high cost and environmentally unfriendly tertiary treatment, whereas mills can simply dose the bioactivator made by AB-101 into the existing system, without additional equipment nor energy.

Apparently, there is a new regulation with $20 \mathrm{mg} / \mathrm{L} \mathrm{BOD}$ is yet to be gazetted effectively, especially within the Peninsular of Malaysia, due to the lack of technology with limited land available for ponding treatment system [30], mills around Malaysia has started to invest on expensive technologies to comply the standard. However, there are track records from the industrial user that straight comply DOE standards (BOD3 below $20 \mathrm{mg} / \mathrm{L}$ ) through biological treatment only by strengthening indigenous microorganisms and further supply more required microorganisms with the aid of $\mathrm{AB} 101$.

\section{Materials and Methods}

\subsection{POME sample collection.}

About $20 \mathrm{~L}$ of raw palm oil mill effluent (POME) will be taken from Tai Tak Palm Oil Mill Sdn Bhd, Kota Tinggi, Johor, by using a freshly bought $30 \mathrm{~L}$ high-density polyethylene (HDPE) container. The raw POME will be collected directly from the pipe inlet of the first (anaerobic) pond that comes from the holding pond. Firstly, once the container was half-filled with POME, the container will be inverted several times to rinse off any impurities from the inside wall of the container. The POME will then be discharged back into the Anaerobic Pond 1. The step will be repeated once more before the final sample will be taken. The container will be labeled properly-the name of the company, type, and date of collection. The sample will be brought back to the UTHM downstream laboratory and will be stored in a cold room that will consistently set to $4^{\circ} \mathrm{C}$ to ensure there is no enzymatic or microbiological activity happening.

\subsection{AB-101 sample and molasses collection.}

About 650 mL AB-101 will be collected from manufacturer AROMDAI Bio Solutions Sdn Bhd, Johor Bahru, Johor. The sample will be collected in readily packaged by the company by using $1 \mathrm{~L}$ ember bottle in aseptic condition. An Ember bottle will be used in order to prevent any lighting or heating from surrounding to penetrate into the content and trigger any possible microbiological reaction. The bottle will also be made sure to be sealed properly with stopper and parafilm to prevent any air coming in that might cause an oxidation reaction. Then, the bottle will be packed into a portable, isolated icebox (5L) containing $3 \mathrm{~kg}$ of dry ice, in order to ensure that any microorganisms exist in AB-101 are in a dormant state. Hence, no biological reaction will occur. Molasses was also obtained from the same company in a $20 \mathrm{~L}$ of clean Jerry Can. 
2.3. Optimization of AB-101 performance using response surface methodology (RSM).

The Design Expert Software (version 7.1.5) will be used for the statistical design of experiments and data analysis. In this study, the central composite design (CCD) and response surface methodology (RSM) will be applied to optimize the three most important operating variables: i) percentage of $\mathrm{AB}-101$ used in bio-activator, (ii) percentage of molasses added in bio-activator, and (iii) dosage volume of bio-activator into the rig of POME in the anaerobic system to determine a narrower range of percentage volume of AB-101 and molasses content in bio-activator prepared and the dosage volume required to treat a respective capacity of POME in the anaerobic system prior to designing the experimental runs. Chemical Oxygen Demand (COD) will be used as a response, or in other words, as a dependent parameter in this method. The range of the variables is based on the preliminary results and as shown in the following Table 1.

Table 1. Range of factors set in design expert software.

\begin{tabular}{l|l|c|c} 
Variables & Name & Unit & Range \\
\hline 1 & Percentage Volume of AB-101 & $\%$ & $0.1-1.0$ \\
\hline 2 & Percentage Volume of molasses & $\%$ & $0-10.0$ \\
\hline 3 & Dosage of bio-activator & $\mathrm{ppm}$ & $20-80$
\end{tabular}

According to the 20 runs generated from the Design-Expert software, every single run was set up by using $1 \mathrm{~L}$ of POME basis by using $1 \mathrm{~L}$ of beaker imitating anaerobic ponds from an open ponding system. Bio-activators were prepared according to the data also from the software in $1 \mathrm{~L}$ beaker and aerated continuously for 48 hours by using a low noise air pump. After 48 hours, the prepared bio-activator was dosed into the beaker containing POME daily according to the details from the software. After five days, the COD of each beaker was determined and recorded back into the software. Then the software analyzes and determines the optimum value of each variable according to the best outcomes recorded. COD of POME was measured by using DR6000 ${ }^{\mathrm{TM}}$ UV-VIS Spectrophotometer (Hach) according to the standard procedure provided by Hach.

\section{Results and Discussion}

Response Surface Methodology (RSM) was employed based on the central composite design (CCD) via Design-Expert software (Stat-Ease Inc., version 7.1.5). The second-order polynomial models indicated the adequacy between the independent variables; (AB101 and molasses percentage in bio-activator and dosing volume of the bio-activator) and the response of COD reduction percentage of the treated POME.

Table 2. Runs are generated by design expert software (with the experimental result of cod reduction percentage).

\begin{tabular}{|c|c|c|c|c|}
\hline \multirow[t]{2}{*}{ Runs } & \multicolumn{3}{|c|}{ Independent Variables } & \multirow[t]{2}{*}{ COD Reduction Percentage } \\
\hline & AB101 & Molasses & Dosage & \\
\hline 1 & 0.55 & 5.00 & 20.0 & 82.97 \\
\hline 2 & 0.55 & 5.00 & 50.0 & 83.56 \\
\hline 3 & 1.00 & 5.00 & 50.0 & 86.39 \\
\hline 4 & 1.00 & 10.00 & 20.0 & 88.40 \\
\hline 5 & 0.55 & 5.00 & 50.0 & 83.79 \\
\hline 6 & 0.55 & 5.00 & 80.0 & 82.69 \\
\hline 7 & 0.55 & 10.00 & 50.0 & 86.21 \\
\hline 8 & 0.10 & 10.00 & 20.0 & 91.23 \\
\hline 9 & 1.00 & 10.00 & 80.0 & 90.46 \\
\hline 10 & 0.55 & 5.00 & 50.0 & 83.33 \\
\hline 11 & 1.00 & 0.00 & 20.0 & 84.02 \\
\hline 12 & 0.55 & 5.00 & 50.0 & 83.74 \\
\hline
\end{tabular}




\begin{tabular}{|c|c|c|c|c|}
\hline \multirow[t]{2}{*}{ Runs } & \multicolumn{3}{|c|}{ Independent Variables } & \multirow[t]{2}{*}{ COD Reduction Percentage } \\
\hline & AB101 & Molasses & Dosage & \\
\hline 13 & 0.10 & 0.00 & 80.0 & 86.30 \\
\hline 14 & 0.55 & 0.00 & 50.0 & 82.47 \\
\hline 15 & 0.55 & 5.00 & 50.0 & 83.56 \\
\hline 16 & 0.10 & 0.00 & 20.0 & 89.45 \\
\hline 17 & 0.55 & 5.00 & 50.0 & 83.74 \\
\hline 18 & 0.10 & 10.00 & 80.0 & 89.82 \\
\hline 19 & 0.10 & 5.00 & 50.0 & 89.13 \\
\hline 20 & 1.00 & 0.00 & 80.0 & 83.33 \\
\hline
\end{tabular}

Using RSM as an optimization tool, 20 runs of experiments are generated via the software. The values of each factor or independent variable were set within the system with a specific sequence, as shown in the following Table 2. All the runs of CCD generated with full $2^{3}$ factorial designs (three factors each at two levels) were employed to identify the effect of three aforementioned independent variables, the volume percentage of AB101 $\left(\mathrm{X}_{1}\right)$, the volume percentage of molasses $\left(\mathrm{X}_{2}\right)$, both in bio-activator preparation and the third variable, dosing volume of the bio-activator $\left(\mathrm{X}_{3}\right)$

\subsection{Interaction Effects of Variables}

3.1.1. Interaction effects of volume percentage of AB101 and molasses in bio-activator.

RSM also generates interaction plots indicating the response of COD reduction as a function of the two factors out of the total three factors within the experimental range. Those aforementioned plots or graphs are significant in order to analyze the interaction between the independent variables (factors) and dependent variable (COD reduction percentage) throughout the experiment in reducing the COD in POME in 5 days treatment using a bioactivator made by microbial consortium, AB101. Figure 1 portrays the interaction plots presenting the effect of both volume percentages of AB101 (variable A) and molasses (variable B) in bio-activator in COD reduction percentage (response) after 5 days at dosing volume (variable $\mathrm{C}$ ) fixed at $50 \mathrm{ppm}$ with respect to the POME capacity.

Generally, at $50 \mathrm{ppm}$ dosing volume, the COD reduction increases as the volume percentage of $\mathrm{AB} 101$ decreases to the minimum $(0.10 \%)$; however, it closely interacts with the volume percentage of molasses. Accordingly, in all values of $\mathrm{A}$, the higher volume percentage of molasses contributes to resulting in greater COD reduction. Therefore, the maximum COD reduction $(91.2 \%)$ results from the lowest volume percentage of $\mathrm{AB} 101$ $(0.10 \%)$ and the highest volume percentage of molasses $(10.0 \%)$.

The pattern of lower COD reduction in higher AB101 only lasts until the volume percentage of $\mathrm{AB} 101$ reaches $0.60 \%$. The $\mathrm{COD}$ reduction percentage tends to increase back as AB101 increased from $0.60 \%$ to $1.0 \%$. Nevertheless, the interaction between the volume percentage of $\mathrm{AB} 101$ and molasses remains consistent, whereas every point of $\mathrm{AB} 101$ requires a higher percentage of molasses in order to come out with greater COD reduction. The pattern explains that the bio-activator has sufficient and the best amount of microorganisms at $0.10 \%$ volume percentage of bio-activator, and increasing A is not necessarily better. Contradictorily, the higher volume percentage of A might contribute to the over-populated of microorganisms present in the POME. Molasses that is rich in both micro- and macronutrients that are supposed to be fed to microbes so that it can grow and perform optimally in reducing organic pollutants in the water now is insufficient due to the over-populated of microbes. Therefore, instead of functioning properly in reducing $\mathrm{COD}$, they tend to auto-digesting each other due to an 
insufficient amount of food with respect to their population. Thus, COD reduction does not go at an optimum rate.

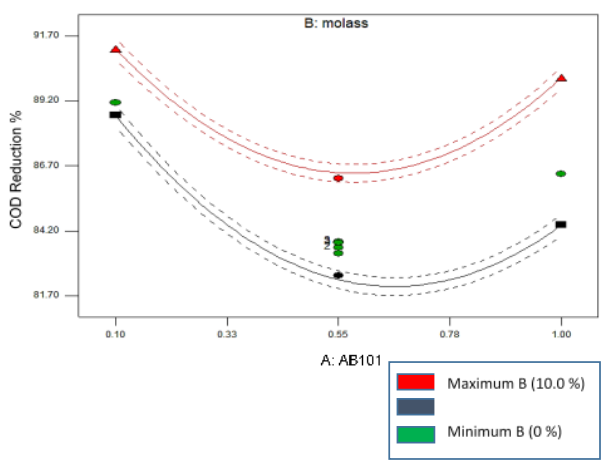

Figure 1. Interaction Plots between volume percentage of AB101 and molasses in reducing COD in POME.

An overall and more detailed interaction between variables A and B is portrayed in the 3D surface (a) and contour (b) plots in the following Figure 2. Accordingly, the peak region possessing the highest COD reduction percentage (91.2\%) is wherein the volume percentage of $\mathrm{AB} 101$ is at the minimum $(0.10 \%)$ and the highest volume percentage of molasses $(10.0 \%)$. Meanwhile, the poorest region, possessing the lowest COD reduction percentage $(82.01 \%)$ results at a volume percentage of $\mathrm{AB} 101(0.65 \%)$ with zero molasses.

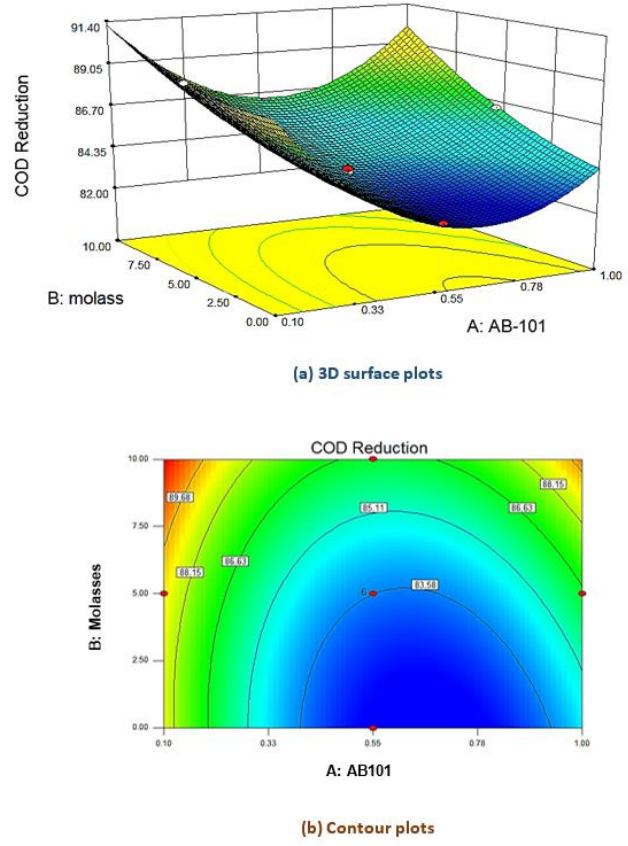

Figure 2. Interaction of volume percentage of AB101 and molasses via 3D surface (a) and contour (b) plots.

3.1.2. Interaction effects of volume percentage of AB101 and dosing volume of bio-activator.

The following interaction plots in Figure 3 illustrates the overall interaction between volume percentage of $\mathrm{AB} 101$ (A) and bio-activator dosing volume (C) in reducing COD in POME in five days at volume percentage of molasses (B) fixed at $5.0 \%$. Accordingly, as the variable $\mathrm{A}$, the volume percentage of $\mathrm{AB} 101$ possessing the lowest value, which is at $0.10 \%$, the response is the maximum, but it directly depends on the variable $\mathrm{C}$, the dosage of the bioactivator. The pattern portrays that at the lowest volume percentage of $\mathrm{AB} 101$, the dosage also 
is required to be at the minimum value $(20 \mathrm{ppm})$ in order to achieve the best outcome of response, COD reduction percentage $(89.5 \%)$.

As the volume percentage of $\mathrm{AB} 101$ increases from $0.10 \%$ to $0.78 \%$, the same pattern of interaction with the dosage is shown. In this range, every value of $\mathrm{A}$, requires a minimum of $\mathrm{C}$ in order to achieve the best result from the response. However, this pattern only remains until the point wherein the volume percentage of AB101 up to $0.78 \%$. From that onwards, the pattern is inversed. At this range $(0.78 \%-1.0 \%)$, the maximum of bio-activator dosage promises a better COD reduction in POME treatment.

Apparently, interacting with each other, the minimum amount of volume percentage of AB101 with minimum bio-activator dosage is the best in obtaining the highest COD reduction percentage. These factors are optimum at the lowest value is to prevent any over-populated beneficial microorganism in the POME system, which can jeopardize the performance of microorganisms with lacking food available.

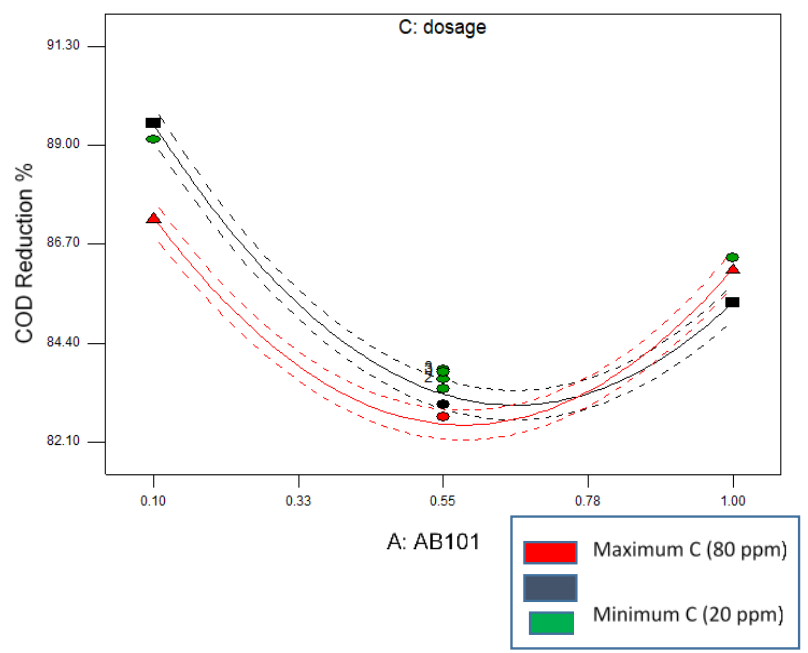

Figure 3. Interaction plots between volume percentage of $\mathrm{AB} 101$ and dosing volume of the bio-activator.

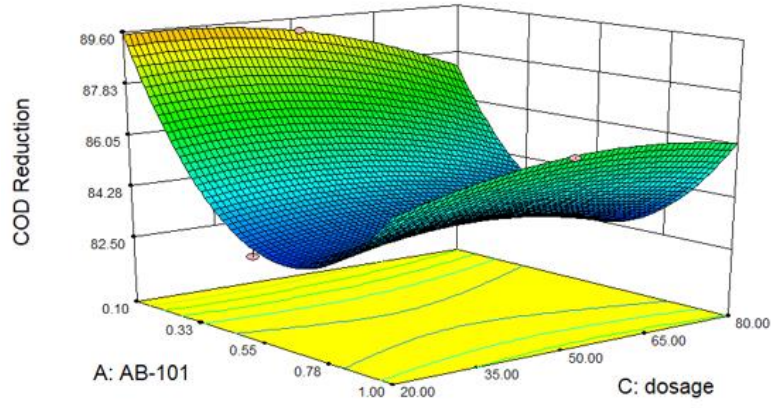

(a) 3D surface plots

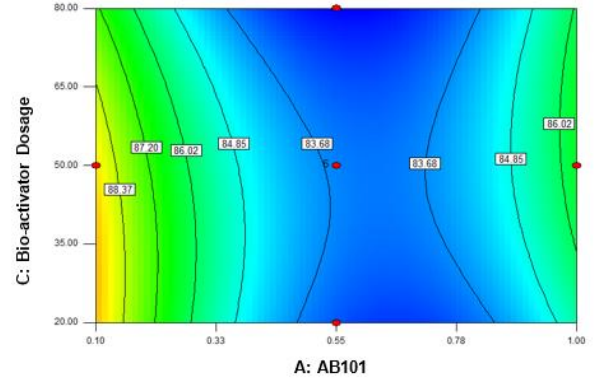

(b) Contour plots

Figure 4. Interaction of volume percentage of $\mathrm{AB} 101$ and dosage of bio-activator via 3D surface (a) and contour (b) plots.

An overall and more detailed interaction between variables $\mathrm{A}$ and $\mathrm{C}$ is presented in the 3D surface (a) and contour (b) plots in the following Figure 4. Accordingly, the peak region possessing the highest COD reduction percentage $(89.5 \%)$ is wherein the volume percentage of $\mathrm{AB} 101$ is at the minimum $(0.10 \%)$ and accompanied by the lowest dosage of the bioactivator with respect to the POME capacity $(20 \mathrm{ppm})$. Meanwhile, the poorest region, possessing the lowest COD reduction percentage $(83.35 \%)$ is resulted at the highest volume percentage of $\mathrm{AB} 101(1.0 \%)$ with also at the lowest dosage of bio-activator (20ppm). 
3.1.3. Interaction effects of volume percentage of molasses and dosing volume of bio-activator.

The following interaction plots in Figure 5, the interaction between volume percentage of molasses (B) and bio-activator dosing volume $(\mathrm{C})$ in reducing COD in POME in five days at $\mathrm{AB} 101$ (A) fixed at $0.55 \%$. Variable $\mathrm{C}$, the dosage of bio-activator, the previous individual effect results in the lower the dosage, the higher the COD reduction percentage. However, in the interaction between the dosage with the volume percentage of molasses, it resulted in slightly different outcomes. The highest COD reduction $(86.45 \%)$, was resulted not from the lowest dosage anymore. Instead, the bio-activator dosage of around 55ppm, which is around the middle of the range, with the highest volume percentage of molasses $(10.0 \%)$, responds in the highest COD reduction.

Every point value of bio-activator dosage, the volume percentage of molasses has interacted significantly as only a higher volume percentage of molasses give a significantly higher COD reduction percentage. Even the least effective dosage (80ppm) exceeds the most effective dosage (20 ppm) in COD reduction percentage of POME after five days than if both interact with a volume percentage of molasses (B). Maximum B has changed the pattern thoroughly, explaining how sufficient food to microbes is vital for their performance hence resulting in optimum COD reduction.

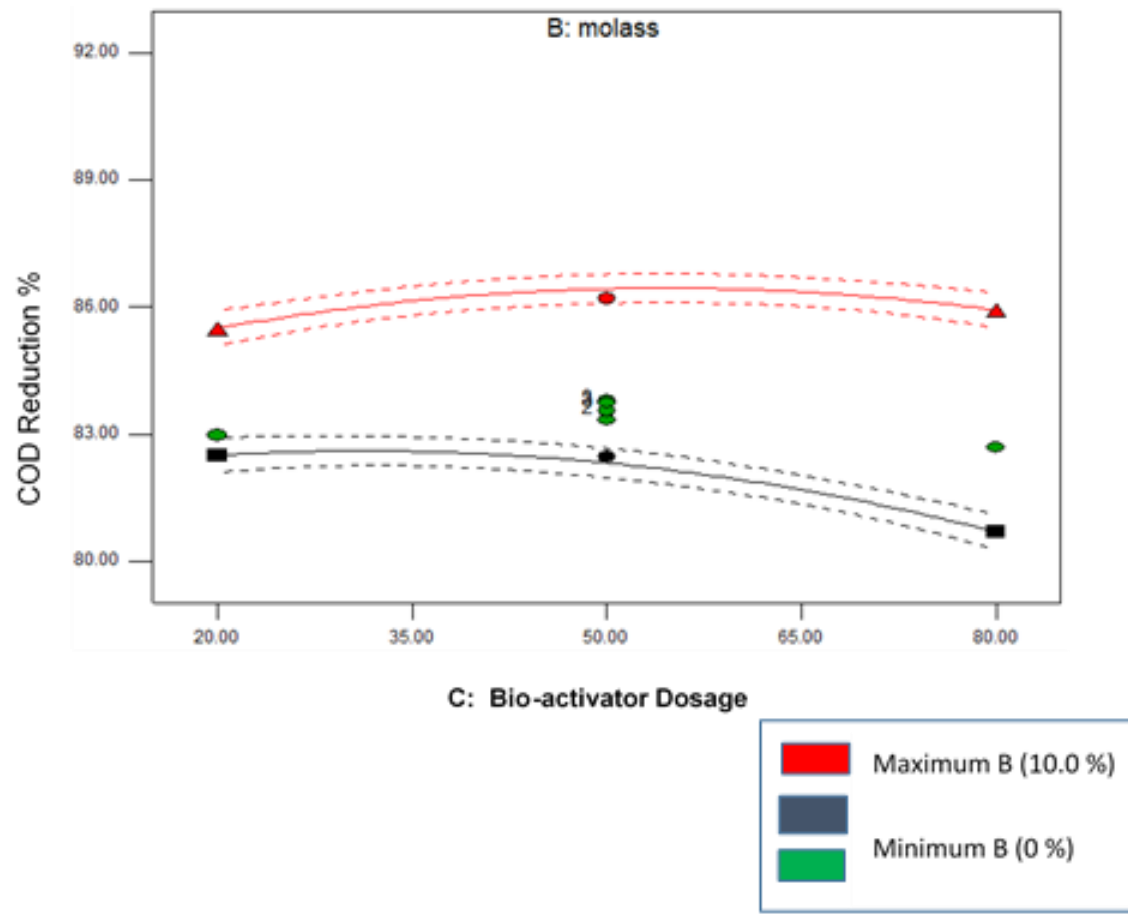

Figure 5. Interaction Plots between volume percentage of AB101 and dosing volume of the bio-activator.

An overall and more detailed interaction between variables $\mathrm{B}$ and $\mathrm{C}$ are presented in the 3D surface (a) and contour (b) plots in the following Figure 6. Accordingly, the peak region possessing the highest COD reduction percentage $(86.54 \%)$ is wherein the volume percentage of molasses is at the maximum (10.0\%) but in the middle of the range in terms of bio-activator dosage, around 55ppm. Meanwhile, the poorest region, possessing the lowest COD reduction percentage $(80.7 \%)$ has resulted in the highest dosage of bio-activator $(80 \mathrm{ppm})$ with zero molasses involved. 


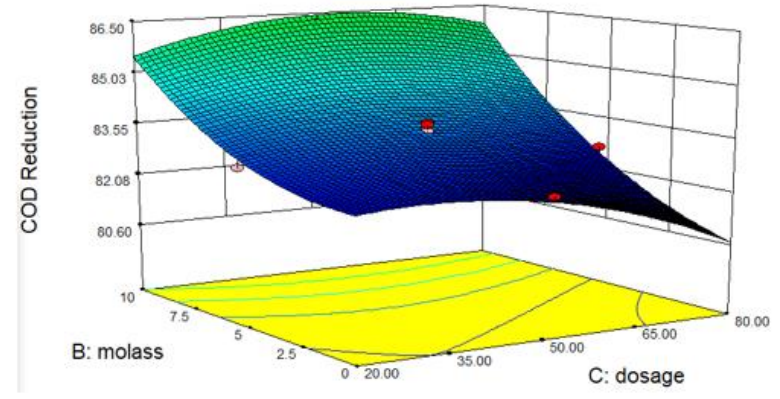

(a) 3D surface plots

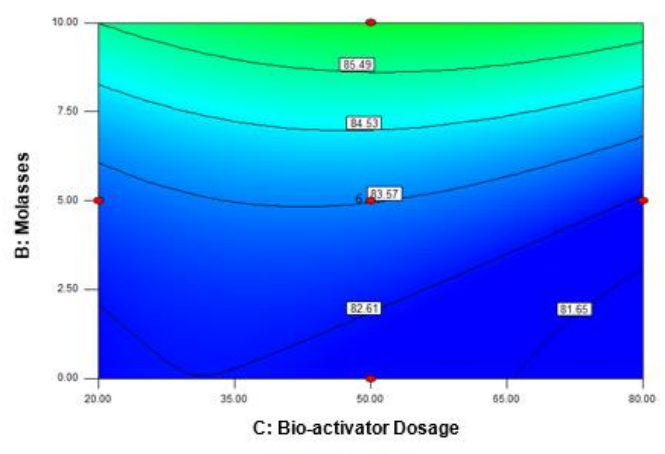

(b) Contour plots

Figure 6. Interaction of volume percentage of molasses and dosage of bio-activator via 3D surface (a) and contour (b) plots.

\subsection{Process optimization and model verification.}

Design expert software provides a number of optimization choices; numerical optimization, graph optimization, and point prediction, all with a respective specific function. Therefore, in this project, in order to determine the optimum value of each independent variable by setting the goal or desired response value. Firstly, in numerical optimization, the desired response generated from the experiments for each run was set as 'maximize' as in we want the optimum value of manipulated variables when the response, COD reduction percentage is maximized. The following Table 3 portrays the optimum value of each variable in order to obtain the maximum COD reduction according to the experiment run according to the model. From the 20 runs generated from the model, the highest COD reduction percentage obtained was 91.25

Table 3. The optimum value of factors analyzed by design expert software.

\begin{tabular}{|c|c|c|c|c|c|}
\hline \multirow[t]{2}{*}{ Variable } & \multirow[t]{2}{*}{ Unit } & \multirow[t]{2}{*}{ Requirement } & \multicolumn{2}{|c|}{ Limit } & \multirow{2}{*}{$\begin{array}{c}\text { Optimum } \\
\text { value }\end{array}$} \\
\hline & & & Lower & Upper & \\
\hline Predicted COD reduction percentage & $\%$ & Maximize & 82.47 & 91.25 & 91.25 \\
\hline Volume percentage of $\mathrm{AB} 101$ & $\%$ & In range & 0.1 & 1.0 & 0.1 \\
\hline Volume percentage of molasses & $\%$ & In range & 1.0 & 10.0 & 9.96 \\
\hline Bio-activator dosage & ppm & In range & 20 & 80 & 33.6 \\
\hline
\end{tabular}

\section{Conclusions}

Conclusively, RSM via Design-Expert software is very convenient in optimizing the variables with experimental justification procedures. Apparently, the volume percentage of AB101 with its nutrition is inverse to each other, whereas the optimum volume percentage of AB101 was recorded at $0.1 \%$, which is the lowest amount set in the system. Meanwhile, the volume percentage of molasses recorded was $9.96 \%$, which is almost the maximum amount set 
in the system (10.0\%). Lastly, the optimum dosage of bio-activator is $33.6 \mathrm{ppm}$ with respect to POME capacity. Thus, it can be concluded that, with a sufficient amount of nutrition, a very minimal amount of AB101, as well as bio-activator, is required, which is the major costeffective factor for industrial application.

\section{Funding}

This research received no external funding.

\section{Acknowledgments}

This research has no acknowledgment.

\section{Conflicts of Interest}

The authors declare no conflict of interest.

\section{References}

1. Ender, G. AgEcon Search Malaysia's Production of Palm Oil with Projections to Year 2000. Malaysia's Prod. Palm Oil with Proj. to Year 2000. 1994.

2. Malaysian Palm Oil Board (MPOB). Production of Crude Palm Oil 2018. Econ. Ind. Dev. Div. 2019. http://bepi.mpob.gov.my/index.php/en/production/production-2019/production-of-crude-oil-palm2019.html (accessed November 15, 2019).

3. Malaysian Palm Oil Board (MPOB). Production of Crude Palm Oil 2019. Econ. Ind. Dev. Div. 2019. http://bepi.mpob.gov.my/index.php/en/production/production-2019/production-of-crude-oil-palm2019.html (accessed September 5, 2020).

4. Azman, I. The Impact of Palm Oil Mills ' Capacity on Technical Efficiency of Palm Oil Millers in Malaysia. 2014, 14.

5. Malaysian Palm Oil Mill Board (MPOB), Number \& Capacities of Palm Oil Sectors 2018. Econ. Ind. Dev. Div. 2019. http://bepi.mpob.gov.my/index.php/en/sectoral-status/sectoral-status-2019/number-a-capacitiesof-palm-oil-sectors-2019.html

6. Rut, J.; Wołczański, T. Increasing the production capacity of the company through the implementation of Computerised Maintenance Management Systems. 2017.

7. Foong, S.Z.Y.; Andiappan, V.; Foo, D.C.Y.; Ng, D.K.S. Flowsheet Synthesis and Optimisation of Palm Oil Milling Processes with Maximum Oil Recovery. Springer Singapore, 2017; https://doi.org/10.1007/978-98113-2236-5.

8. Foo, D.C.Y. Green Energy and Technology Green Technologies for the Oil Palm Industry. Springer Singapore, 2019; https://doi.org/10.1007/978-981-13-2236-5.

9. Bala, J.D.; Lalung, J.; Al-Gheethi, A.A.S.; Kaizar, H.; Ismail, N. Reduction of Organic Load and Biodegradation of Palm Oil Mill Effluent by Aerobic Indigenous Mixed Microbial Consortium Isolated from Palm Oil Mill Effluent (POME). Water Conservation Science and Engineering 2018, 3, 139-156, https://doi.org/10.1007/s41101-018-0043-9.

10. Choong, Y.Y.; Chou, K.W.; Norli, I. Strategies for improving biogas production of palm oil mill effluent (POME) anaerobic digestion: A critical review. Renewable and Sustainable Energy Reviews 2018, 82, 29933006, https://doi.org/10.1016/j.rser.2017.10.036.

11. Yap, C.C.; Chan, Y.J.; Loh, S.K.; Supramaniam, C.V.; Soh, A.C.; Chong, M.F.; Chew, C.L.; Lim, L.K. Comparison of different industrial scale palm oil mill effluent anaerobic systems in degradation of organic contaminants and kinetic performance. Journal of Cleaner Production 2020, 262, https://doi.org/10.1016/j.jclepro.2020.121361.

12. Tabassum, S.; Zhang, Y.; Zhang, Z. An integrated method for palm oil mill effluent (POME) treatment for achieving zero liquid discharge-A pilot study. Journal of Cleaner Production 2015, 95, 148-155, https://doi.org/10.1016/j.jclepro.2015.02.056.

13. Tan, D.T.; Chin, S.K.; Poh, P.E.; Lee, Y.H. Preservation of thermophilic mixed culture for anaerobic palm oil mill effluent treatment by convective drying methods. International Journal of Environmental Science and Technology 2018, 15, 1211-1222, https://doi.org/10.1007/s13762-017-1486-9.

14. Iskandar, M.J.; Baharum, A.; Anuar, F.H.; Othaman, R. Palm oil industry in South East Asia and the effluent treatment technology-A review. Environmental Technology \& Innovation 2018, 9, 169-185, https://doi.org/10.1016/j.eti.2017.11.003.

15. Hayawin, Z. A review on the development of palm oil mill effluent (POME) final discharge polishing 
treatments. Journal of Oil Palm Research 2018, 29, 528-540, https://doi.org/10.21894/jopr.2017.00012.

16. Poh, P.E.; L.C.S.; Wu, T.Y.; Lam, W.H.; Poon, W.C. Introduction. In: Waste Management in the Palm Oil Industry. 2020; https://doi.org/10.1007/978-3-030-39550-6_1.

17. Ali Amat, N.A.; Tan, Y.H.; Lau, W.J.; Lai, G.S.; Ong, C.S.; Mokhtar, N.M.; Sani, N.A.A.; Ismail, A.F.; Goh, P.S.; Chong, K.C.; Lai, S.O. Tackling colour issue of anaerobically-treated palm oil mill effluent using membrane technology. Journal of Water Process Engineering 2015, 8, 221-226, https://doi.org/10.1016/j.jwpe.2015.10.010.

18. Asis, A.J.; Affiq, M.; Arifin, M.; Ngteni, R.; Tahiruddin, S. Palm Oil Mill Effluent Tertiary Treatment By Physicochemical Treatment Using Ferrous Sulphate. Iranica Journal of Energy \& Environment 2016, 7, 163-168.

19. Poh, P.E.; Ong, W.Y.J.; Lau, E.V.; Chong, M.N. Investigation on micro-bubble flotation and coagulation for the treatment of anaerobically treated palm oil mill effluent (POME). Journal of Environmental Chemical Engineering 2014, 2, 1174-1181, https://doi.org/10.1016/j.jece.2014.04.018.

20. Ng, K.H.; Cheng, C.K. Photo-polishing of POME into CH4-lean biogas over the UV-responsive ZnO photocatalyst. Chemical Engineering Journal 2016, 300, 127-138, https://doi.org/10.1016/j.cej.2016.04.105.

21. Sidik, D.A.B.; Hairom, N.H.H.; Mohammad, A.W. Performance and fouling assessment of different membrane types in a hybrid photocatalytic membrane reactor (PMR) for palm oil mill secondary effluent (POMSE) treatment. Process Safety and Environmental Protection 2019, 130, 265-274, https://doi.org/10.1016/j.psep.2019.08.018.

22. Mohammed, R.R.; Chong, M.F. Treatment and decolorization of biologically treated Palm Oil Mill Effluent (POME) using banana peel as novel biosorbent. Journal of Environmental Management 2014, 132, 237-249, https://doi.org/10.1016/j.jenvman.2013.11.031.

23. Ibrahim, I.; Hassan, M.A.; Abd-Aziz, S.; Shirai, Y.; Andou, Y.; Othman, M.R.; Ali, A.A.M.; Zakaria, M.R. Reduction of residual pollutants from biologically treated palm oil mill effluent final discharge by steam activated bioadsorbent from oil palm biomass. Journal of Cleaner Production 2017, 141, 122-127, https://doi.org/10.1016/j.jclepro.2016.09.066.

24. Remy, C.; Miehe, U.; Lesjean, B.; Bartholomäus, C. Comparing environmental impacts of tertiary wastewater treatment technologies for advanced phosphorus removal and disinfection with life cycle assessment. Water Science and Technology 2014, 69, 1742-1750, https://doi.org/10.2166/wst.2014.087.

25. Rahman, S.M.; Eckelman, M.J.; Onnis-Hayden, A.; Gu, A.Z. Life-Cycle Assessment of Advanced Nutrient Removal Technologies for Wastewater Treatment. Environmental Science \& Technology 2016, 50, 30203030, https://doi.org/10.1021/acs.est.5b05070.

26. Ganapathy, B.; Yahya, A.; Ibrahim, N. Bioremediation of palm oil mill effluent (POME) using indigenous Meyerozyma guilliermondii. Environ Sci Pollut Res 2019, 26, 11113-11125. https://doi.org/10.1007/s11356-019-04334-8

27. Yang, G.; Yin, Y.; Wang, J. Microbial community diversity during fermentative hydrogen production inoculating various pretreated cultures. International Journal of Hydrogen Energy 2019, 44, 13147-13156. https://doi.org/10.1016/j.ijhydene.2019.03.216.

28. Rosa, D.; Pedroni Medeiros, A. B.; Martinez-Burgos, W. J.; do Nascimento, J. R.; de Carvalho, J. C.; Sydney, E. B.; Soccol, C. R. Biological Hydrogen Production from Palm Oil Mill Effluent (POME) by Anaerobic Consortia and Clostridium beijerinckii. Journal of Biotechnology 2020, https://doi:10.1016/j.jbiotec.2020.06.015.

29. Prasetyo, J.; Senda, S. P.; Wulandari, W.; Anindita, N. N. Bio-CSTR for biogas production from POME treatment - technology: Design and analysis. The 5th International Conference On Industrial, Mechanical, Electrical, And Chemical Engineering 2019 (ICIMECE 2019), https://doi:10.1063/5.0000783.

30. Chan Y.J.; Chong M.F. Palm Oil Mill Effluent (POME) Treatment-Current Technologies, Biogas Capture and Challenges. In: Foo D., Tun Abdul Aziz M. (eds) Green Technologies for the Oil Palm Industry. Green Energy and Technology. Springer, Singapore 2019, https://doi.org/10.1007/978-981-13-2236-5_4. 